\title{
Pemberdayaan Masyarakat Melalui Penerapan Web Potensi Desa Di Desa Lalumpe Kecamatan Motoling Kabupaten Minahasa Selatan
}

\author{
Olivia E.S Liando, ST, M.Sc, M.Pd \\ Jurusan PTIK Fakultas Teknik Universitas Negeri Manado \\ E-mail: olivialiando@unima.ac.id
}

\begin{abstract}
Abstrak
Program ini merupakan program yang bertujuan sebagai proses pengabdian dan pembelajaran bagi dosen dan mahasiswa sekaligus wahana pemberdayaan masyarakat. Program ini dilaksanakan di Desa lalumpe Kecamatan Motoling Kabupaten Minahasa Selatan yang memiliki potensi desa yang cukup memadai namun belum dioptimalkan. Memberdayakan potensi-potensi desa yang ada sekarang serta memperkenalkannya kepada masyarakat luas merupakan salah satu bentuk upaya pengembangan desa. Upaya tersebut perlu ada pendampingan yang didukung dengan penerapan Ipteks agar bisa memberi hasil yang optimal. Teknologi yang akan digunakan untuk mengatasi permasalahan kelompok sasaran adalah pemanfaatan teknologi informasi dan komunikasi untuk media promosi pengenalan potensi desa dan pemasaran hasil desa. Pelaksanaan program KKN PPM Pemberdayaan Masyarakat Melalui Penerapan Web Potensi Desa Di Desa Lalumpe Kecamatan Motoling Kabupaten Minahasa Selatan ini mendapatkan respon yang positif dari masyarakat dan pemerintah, karena program yang dilaksanakan sesuai dengan permasalahan dan kebutuhan desa. Hasil yang di capai dalam pelaksanaan KKN PPM ini diantaranya adalah Adanya Profil desa dan Master plan dan Web Potensi Desa sebagai salah satu media online promosi dan pemasaran potensi desa, Penguatan Tata Kelola/Manajemen Potensi Desa yang baik dan jelas, meningkatnya keterampilan masyarakat mengelola potensi desa, meningkatnya kesadaran dan motivasi warga desa untuk memberdayakan potensi desa dengan membentuk kelompok usaha tani.
\end{abstract}

Kata Kunci: Pemberdayaan Masyarakat, Potensi Desa, Teknologi Informasi dan Komunikasi

\section{PENDAHULUAN}

Pelaksanaan kegiatan KKN-PPM khususnya di pedesaan merupakan salah satu program pemerintah dalam rangka meningkatkan peran perguruan tinggi dalam pembangunan desa. Dari data yang ada, di Indonesia terdapat 4,91 juta mahasiswa di 4.314 Perguruan Tinggi. Terdapat 79 Perguruan Tinggi yang telah menandatangani MOU dengn Kemeterian Desa untuk melaksanakan program peningkatan peran perguruan tinggi di pedesaan termasuk Unima. Terdapat 4 program utama yang dilaksanakan yaitu : Pengembangan Sumber Daya Alam, Pengembangan Sumber Daya Manusia, Pengembangan Teknologi Tepat Guna, serta Pengembangan Perekonomian Desa. Selain itu juga 6 program Kampus Merdeka yang dikeluarkan oleh Kemendikbud yang salah satunya adalah 
Proyek di desa merupakan bentuk program yang harus diimplementasikan oleh perguruan tinggi.

Unima melalui LPPM yang bertajuk "Unima Membangun Desa" melaksanakan program KKN PPM sebagai realisasi dari peran perguruan tinggi bagi pedesaan. Program kegiatan KKN-PPM bertujuan untuk mengembangkan dan mengimplementasikan kompetensi yang dimiliki oleh dosen dan mahasiswa serta memberdayakan masyarakat dan potensi desa yang ada melalui pengalaman nyata di masyarakat dan menyiapkan mahasiswa untuk bersosialisasi secara langsung dengan masyarakat pada waktu yang akan datang.

Program KKN-PPM dilaksanakan di salah satu desa yang ada di Kabupaten Minahasa Selatan yaitu Desa Lalumpe. Desa Lalumpe yang merupakan sebuah desa yang terletak di Kecamatan Motoling, Kabupaten Minahasa Selatan. Luas wilayah desa ini 1.650 Ha. Desa ini memiliki potensi sumber daya alam yang sangat melimpah. Pertanian masih menjadi sektor andalan bagi Desa Lalumpe. Hal ini dilihat dari keadaan wilayah yang menghasilkan hasil pertanian dan perkebunan yang baik, seperti Cengkeh, Padi, Kelapa. Ada juga beberapa peternakan babi dan ayam. Selain potensi dari segi pertanian, desa ini juga memiliki potensi wisata yang menjanjikan. Dari sumber yang diperoleh, Desa ini terkenal dengan adanya lokasi Air Mujizat. Sekitar 95\% mata pencaharian penduduknya berasal dari sektor pertanian (pertanian lahan sawah, perkebunan kelapa dan cengkeh, pengolahan cap tikus dan gula aren serta peternakan), Selain itu penduduk desa Lalumpe berprofesi sebagai ASN, pedagang dan wiraswasta. Tingkat pendidikan di desa ini, bias dikatakan cukup tinggi, karena dari sumber yang ada, sekitar $95 \%$ penduduknya bersekolah. Hanya sekitar 5\% yang hanya mengenyam bangku SD. Itupun adalah para orang yang sudah lanjut usia. Di desa ini sendiri terdapat 2 Sekolah Dasar dan 1 SMP.

Dari analisis situasi, dapat dikatakan bahwa desa ini memiliki potensi sumber daya alam dan sumber daya manusia yang memadai. Dari datadata tersebut mengindikasikan bahwa sektor pertanian merupakan bidang strategis sehingga perlu mendapat prioritas. Perlu adanya upaya pengembangan desa dengan memanfaatkan potensi-potensi desa yang ada sekarang ini. Memberdayakan potensi-potensi desa yang ada sekarang serta memperkenalkannya kepada masyarakat luas merupakan salah satu bentuk upaya pengembangan desa.

Persoalan yang dijumpai di Desa Lalumpe Kecamatan Motoling Kabupaten Minahasa Selatan, antara lain:

1. Tidak adanya perencanaan pengembangan desa dengan memanfaatkan potensi desa.

2. Promosi/pemasaran potensi desa kurang optimal

3. Tata kelola kelembagaan, manajemen potensi desa yang masih kurang

Berdasarkan dari identifikasi permasalahan tersebut, permasalahan tersebut akibat dari:

\section{Tidak adanya perencanaan pengembangan desa dengan memanfaatkan potensi desa.}

Peran pemerintah desa sangat diperlukan dalam perencaaan dan pengembangan potensi desa baik untuk perencanaan jangka pendek, menengah dan panjang dengan melibatkan semua unsur elemen masyarakat. Ketiadaan keterlibatan pemerintah desa tersebut menjadikan potensi desa di Desa Lalumpe tidak terdokumentasikan secara jelas dalam bentuk dokumen perencanaan pengembangan potensi desa.

Permasalahan tersebut akibat dari pertama, Kemampuan SDM masyarakat dan pengelola terbatas dalam membuat 
perencanaan. Kedua ketiadaan SDM yang mampu memotret potensi desa baik dari segi pertanian mapun wisata (Profil Potensi Desa) . Ketiga tidak adanya SDM yang mampu membuat perencaaan dalam gambar masterplan. Persoalan persoalan tersebut di atas merupakan persoalan yang harus segera diselesaikan supaya Potensi Desa Lalumpe dapat dikembangkan dan dikenalkan kepada masyarakat luas berdasarkan nilai-nilai kearifan lokal masyarakat dalam mendukung pengembangan potensi Desa Lalumpe.

\section{Promosi/pemasaran potensi desa kurang optimal}

Promosi dan Pemasaran merupakan ujung tombak keberhasilan suatu desa untuk lebih dikenal. Keterbatasan sumber daya manusia dalam memperkenalkan potensi desa berakibat belum maksimalnya pengelolaan potensi desa dan masih banyak masyarakat luar yang tidak mengetahui potensi yang ada di desa ini.

Perkembangan ICT belum dimanfaatkan secara optimal sebagai media promosi dan pemasaran. Hal ini bisa dilihat dari akun social media Desa Lalumpe tidak menggambarkan potensi desa yang ada. Selain itu video promosi yang ada hanya menampilkan profil dan keadaan desa secara umum.

\section{Tata kelola kelembagaan, manajemen potensi desa yang masih kurang}

Belum adanya pengelola yang khusus mengelola potensi desa menjadikan permasalahan tersendiri bagi pemerintah Desa Lalumpe, dimana pengelolaan potensi desa dikelola langsung oleh pemerintah Hal tersebut akibat dari kurangnya persiapan sumber daya manusia (SDM) pengelola, baik dari sisi pengetahuan atau keterampilan dalam mengelola data potensi desa.

\section{METODE}

Dalam mengatasi permasalahan tersebut diatas maka metode yang digunakan supaya program dapat berkelanjutan adalah dengan melakukan pelatihan, implementasi, pendampingan, dan jejaringan sehingga kegiatan tersebut diuraikan sebagai berikut :

1. Pendampingan penguatan sumber daya manusia melalui pendampingan tata kelola/manajemen, motivasi berwirausaha, pemasaran dan peningkatan ketrampilan

2. Pendampingan penyusunan paket potensi desa

3. Pendampingan perencanaan partisipatif (masterplan integratif dan profil Desa)

\section{HASIL DAN PEMBAHASAN}

Program kegiatan KKN PPM dilaksanakan melalui beberapa mekanisme tahapan, yaitu tahap persiapan, tahap pelaksanaan serta tahap evaluasi dan pelaporan.

\section{Tahapan Persiapan}

Untuk pelaksanaan KKN PPM ini selalu diawali dengan tahapan persiapan, yaitu perekrutan mahasiswa KKN dan mempersiapkan pembekalan bagi mahasiswa.

Perekrutan mahasiswa peserta KKN PPM dilakukan oleh LPPM dengan memperhatikan relevansi keilmuan mahasiswa bersangkutan dengan tema kegiatan.

Pelaksanaan pembekalan ini bertujuan untuk mendekatkan pemahaman mahasiswa terhadap kebutuhan tema program yang akan dilaksanakan oleh mahasiswa. Tahapan pembekalan mahasiswa KKN PPM berdasarkan disesuaikan kebutuhan tema program, yaitu pembekalan materi ilmu terapan sesuai disiplin ilmu masingmasing mahasiswa. Mulai materi umum, materi administrasi, materi kemasyarakatan, materi kewirausahaan, materi kecakapan khusus dan materi manajemen dan program KKN PPM. 
Selain itu juga mahasiswa dibekali dengan Pengenalan Potensi Wilayah dan karakteristik masyarakat tempat pelaksanaan kegiatan.

\section{Tahapan Pelaksanaan/Realisasi Program}

Metode yang diterapkan dalam pelaksanaan kegiatan KKN PPM ini adalah sebagai berikut:

a. Kordinasi dan komunikasi secara partisipasif dengan pemerinta dan masyarakat sasaran untuk merumuskan program mulai dari perencanaan, operasional dan evaluasi

b. Penyuluhan untuk membangun persepsi dan pemahaman masyarakat mengenai inovasi atau program yang diterapkan,

c. Pelatihan dan simulasi mengenai terapan Ipteks yang dialihkan bagi masyarakat

d. Pendampingan yaitu pertemuan secara berkala dan berkelanjutan antara pendamping dengan masyarakat sasaran hingga ipteks yang dialihkan dapat dilaksanakan secara mandiri oleh masyarakat.

Untuk pelaksanaan KKN telah dilakukan koordinasi dan sosialisasi program-program kepada pemerintah dan masyarakat sasaran, yaitu mempersiapkan masyarakat sasaran untuk terlibat kegiatan yang disepakati bersama masyarakat. Mahasiswa KKN menjalankan program kegiatan dimulai dari proses pertemuan bersama masyarakat sasaran, dimaksud mewujudkan atau membangun kesepahaman dan kesepakatan dalam kerjasama pelaksanaan KKN PPM.

Langkah-langkah operasional yang dilakukan dalam kegiatan $\mathrm{KKN}$ PPM ini diantaranya :

a. Koordinasi dan Sosialisasi Program Kerja dengan pemerintah Desa Lalumpe b. Sosialisasi pemanfaatan TIK kepada guru-guru dan siswa SD GP Lalumpe

c. Bakti social dengan masyarakat

d. Wawancara dengan beberapa warga dari berbagai profesi dan usaha pertanian

e. Turun ke lokasi-lokasi pertanian warga dan lokasi air mujizat

f. Pendampingan tatakelola/manajemen kepada perangkat desa tentang pengelolaan potensi desa

g. Memperkenalkan usaha-usaha pengolahan hasil pertanian dan cara-cara berwirausaha

h. Pembuatan video, profil desa dan master plan dan website potensi Desa Lalumpe

i. Sosialisasi Web Potensi Desa Lalumpe

j. Pendampingan Promosi melalui Media Online

\section{Kendala dan Hambatan yang dihadapi}

Dalam pelaksanaan kegiatan dihadapi beberapa kendala yang menjadi hambatan, yaitu :

1. Waktu pelaksanaan kegiatan yang singkat

2. Kurangnya motivasi berwirausaha dalam masyarakat

3. Rendahnya kesadaran mayarakat untuk mengembangkan potensi dari masyarakat.

4. Lokasi geografis desa yang mengakibatkan kurang stabilnya jaringan komunikasi dan internet

\section{Rencana Keberlanjutan Program dan Evaluasi}

Pengembangan desa tidak cukup dilakukan dalam waktu singkat, melainkanmembutuhkan waktu panjang dan berkesinambungan. Oleh sebab itu, untuk menjamin keberlanjutan program ini maka akan dilakukan pendampingan yang berlanjut baik oleh internal perguruan tinggi maupun melibatkan 
mitra. Pendampingan perguruan tinggi direncanakan melalui penempatan mahasiswa KKN PPM pada gelombang berikutnya dengan program kegiatan yang lebih bervariatif dan inovatif.

\section{Hasil Kegiatan}

1. Adanya Profil desa dan Master plan dan Web Potensi Desa sebagai salah satu media online promosi dan pemasaran potensi desa.

2. Penguatan Tata Kelola/Manajemen Potensi Desa yang baik dan jelas

3. Adanya keterampilan masyarakat mengelola potensi desa

4. Adanya kesadaran dan motivasi warga desa untuk memberdayakan potensi desa dengan membentuk kelompok usaha tani

\section{Dokumentasi Kegiatan}
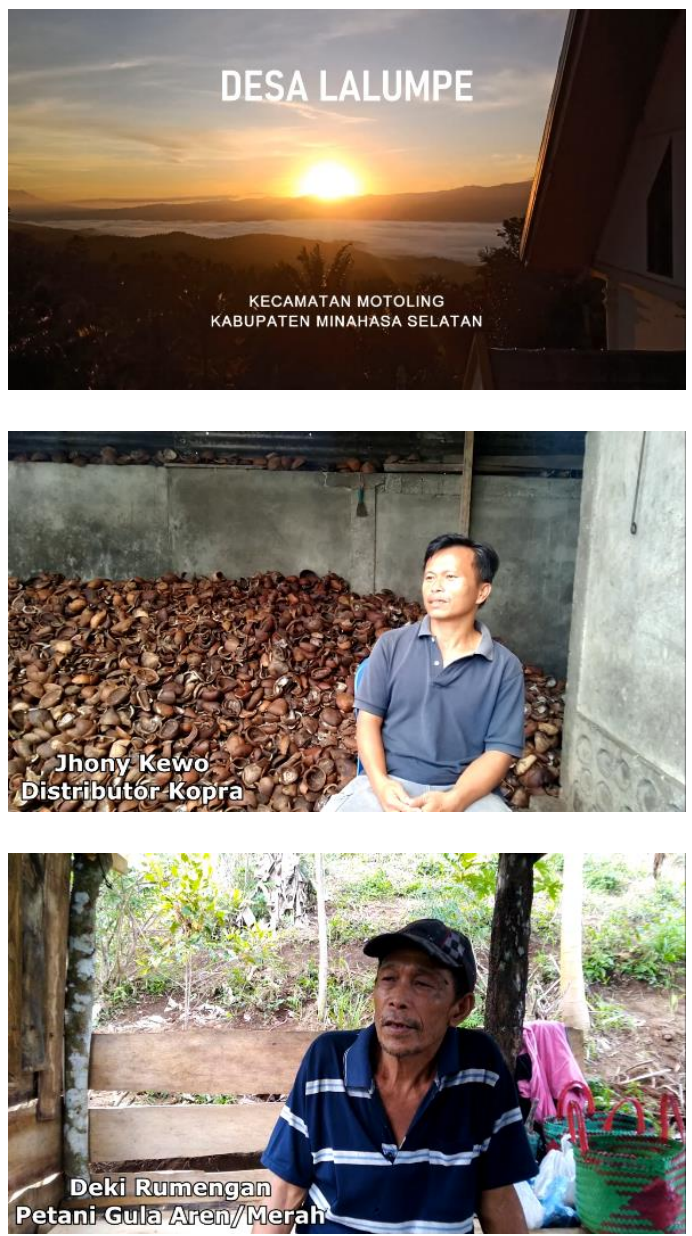
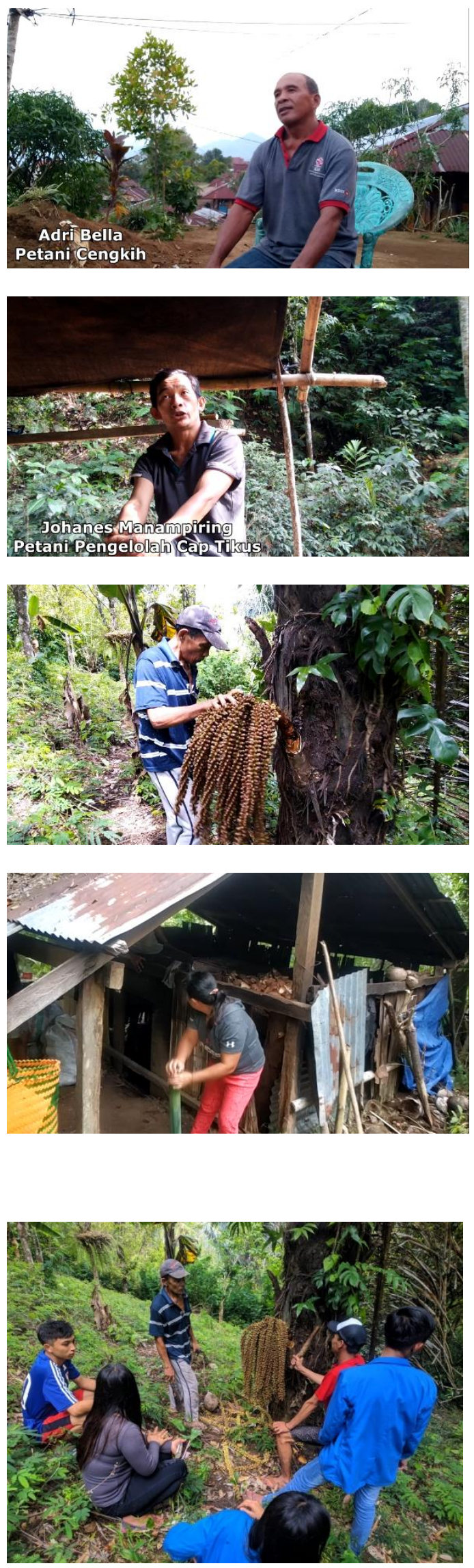
Jurnal ABDIMAS, Vol. 13, No. 2, Agustus 2020

ISSN: 1979-0953 | e-ISSN: 2598-6066
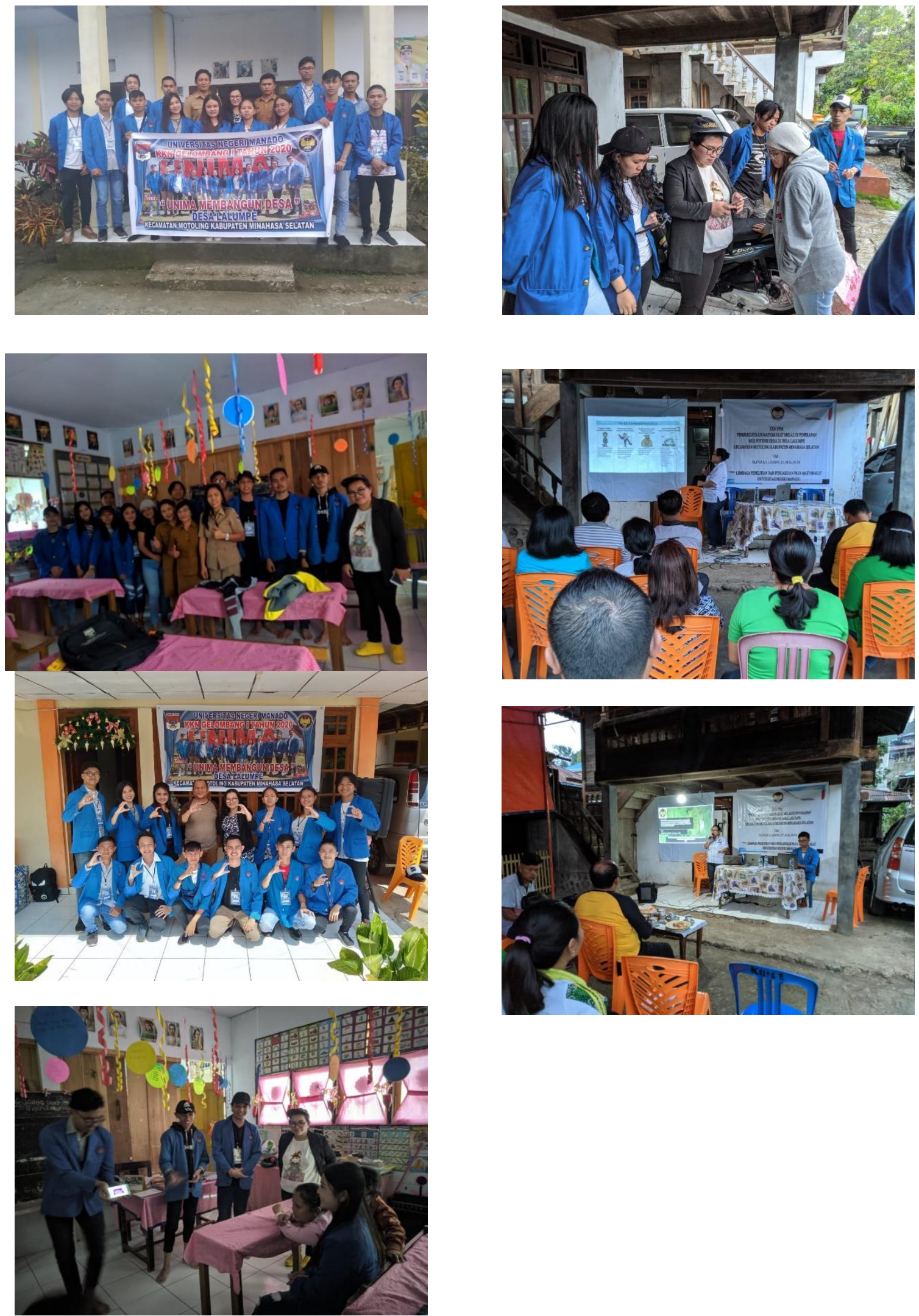


\section{KESIMPULAN}

Pelaksanaan program KKN PPM Pemberdayaan Masyarakat Melalui Penerapan Web Potensi Desa Di Desa Lalumpe Kecamatan Motoling Kabupaten Minahasa Selatan ini mendapatkan respon yang positif dari masyarakat dan pemerintah, karena program yang dilaksanakan sesuai dengan permasalahan dan kebutuhan desa. Hasil yang di capai dalam pelaksanaan KKN PPM ini diantaranya adalah Adanya Profil desa dan Master plan dan Web Potensi Desa sebagai salah satu media online promosi dan pemasaran potensi desa, Penguatan Tata Kelola/Manajemen Potensi Desa yang baik dan jelas, meningkatnya keterampilan masyarakat mengelola potensi desa, meningkatnya kesadaran dan motivasi warga desa untuk memberdayakan potensi desa dengan membentuk kelompok usaha tani.

\section{REFERENSI}

Adisasmita R. 2006. Pembangunan Pedesaan dan Perkotaan. Yogyakarta (ID): Graha Ilmu

Firdaus, I. dan Riyanto. 2016. Perancangan Website Pemerintah Desa sebagai Media Penyebaran Informasi bagi Masyarakat dengan Metode Waterfall. Jurnal Sainstech.2 (6): 34-40

\section{GDM (Gerakan Desa Membangun).}

2014. Permasalahan dan Langkah

Strategis Penerapan TIK di

Perdesaan. Sumber:

http://desamembangun.or.id/2014/

06/per masalahan-dan-langkah-

strategispenerapan-tik-di-

perdesaan/

Leeuwis C. 2009. Komunikasi untuk Inovasi Pedesaan. Yogyakarta (ID): Kanisius.
Lucas Henry J. 2000. Information

Technology for Management. Irwin/MacGraw Hill, 2000

Nandari, B. A. dan Sukadi. 2014.

Pembuatan Website Portal Berita

Desa Jetis Lor. IJNS - Indonesian Journal on Networking and Security. 3(3): 43-47 Raharjo, Budi. 2011. Belajar Pemograman Web. Bandung: Modula.

Sitompul, RF. 2009. Merancang Model Pengembangan Mayarakat Pedesaan dengan Pendekatan System Dynamics. Jakarta (ID): LIPI Press.

Supriyanta dan Khoirun Nisa. 2015.

Perancangan Website Desa Wisata Karangrejo Sebagai Media Informasi Dan Promosi. Jurnal Bianglala Informatika. 3(1): 3540.

Suyanto, M. 2003. Multimedia (alat untuk meningkatkan keunggulan bersaing). Yogyakarta : Penerbit Andi, 2003 